\title{
The Long-Term Unemployed in the Wake of the Great Recession
}

\section{Percent of Unemployed Americans Seeking Work for Longer Than Six Months More Than Doubled Between 2007 and 2013}

Andrew Schaefer

$\mathrm{E}$ ach month the Bureau of Labor Statistics (BLS) reports employment figures for the United States. ${ }^{1}$ These figures have served as a barometer of the country's relative economic strength for the last seventy years and recently have highlighted unemployment's rise throughout the Great Recession. Often overlooked, ${ }^{2}$ however, are figures related to the so-called "long-term" unemployed, those unemployed for longer than twenty-six weeks, roughly six months. While the unemployment rate has slowly receded after a peak of about 10 percent during the Great Recession between December 2007 and June 2009, the long-term unemployment rate remains staggeringly high at more than a third ( 39 percent) of all unemployed. ${ }^{3}$ This is cause for concern given that workers in most states are eligible for a maximum twenty-six weeks of basic unemployment insurance, and the federal extension of unemployment benefits that would have provided, at most, thirty-eight weeks of benefits expired on January 1 of this year. ${ }^{4}$ Given the significant numbers of individuals involved, the long-term unemployed are an important group to monitor.

But what are the characteristics of the long-term unemployed? And how do these characteristics vary across place? We know surprisingly little about these questions. ${ }^{5}$ Using the Annual Social and Economic Supplement (ASEC) of the Current Population Survey (CPS), this brief outlines the demographic and economic characteristics of the long-term unemployed and compares them with their short-term unemployed counterparts (See Box 1 on page 7 for definitions of short- and long-term unemployed used

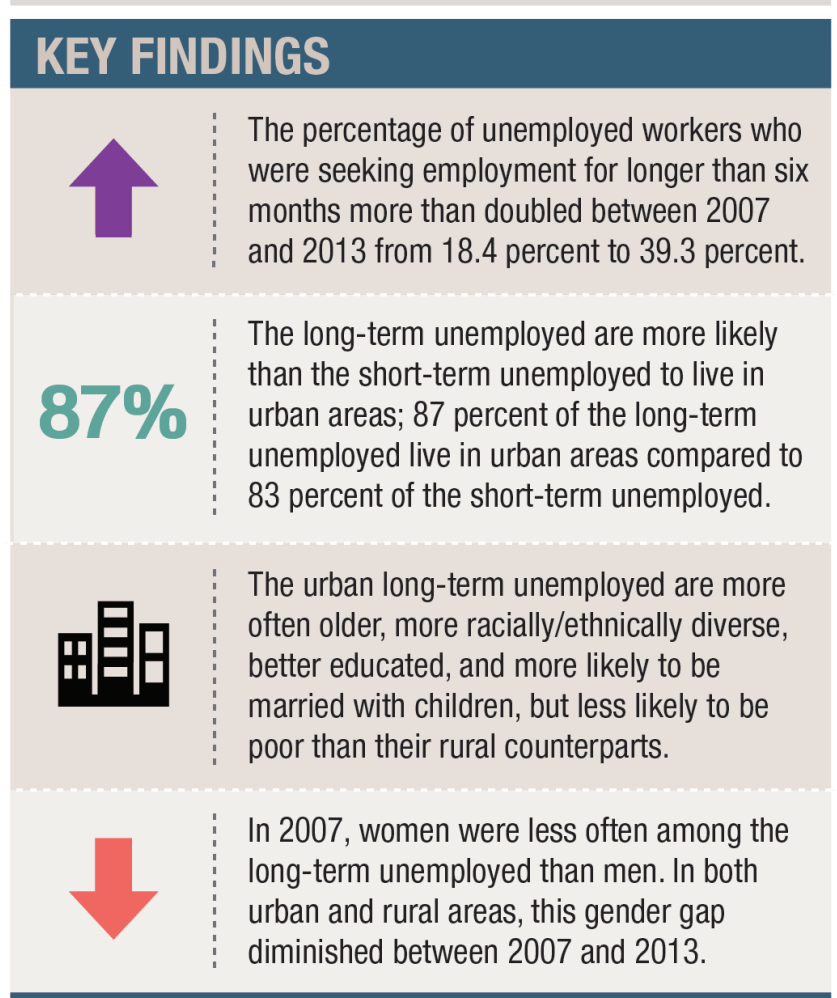

here). It also describes changes in the composition of the long-term unemployed since the start of the Great Recession.

We find several distinctions. The long-term unemployed are more likely than short-term unemployed to be older, have higher levels of education, and be nonHispanic black. The long-term unemployed also have lower median family incomes and are more likely to be in poverty than the short-term unemployed. 
The long-term unemployed also differ depending on where they live. The urban long-term unemployed are older, have more education, and are more racially diverse than their rural counterparts. The rural long-term unemployed have lower median family incomes and are more likely to be impoverished.

\section{Long-Term Unemployment Has Increased Dramatically Since the Start of the Great Recession}

Figure 1 shows the rapid growth in the long-term unemployed at the depth of the recession (2009-2010). Overall unemployment rates also rose rapidly during the Great Recession, but they have since declined to just below 8 percent in 2013 from a high of approximately 10 percent in 2010. In contrast, the percentage of long-term unemployed, as a proportion of all unemployed, has stayed persistently high since then. Between 2007 and 2013, the long-term unemployed more than doubled to approximately 39 percent of the unemployed today. Figure 2 tracks monthly patterns of the long-term unemployed over one year, 2013, and demonstrates the persistence of the high rates over the past year.

\section{FIGURE 1: UNEMPLOYMENT RATE AND LONG-TERM} UNEMPLOYED, 2007-2013

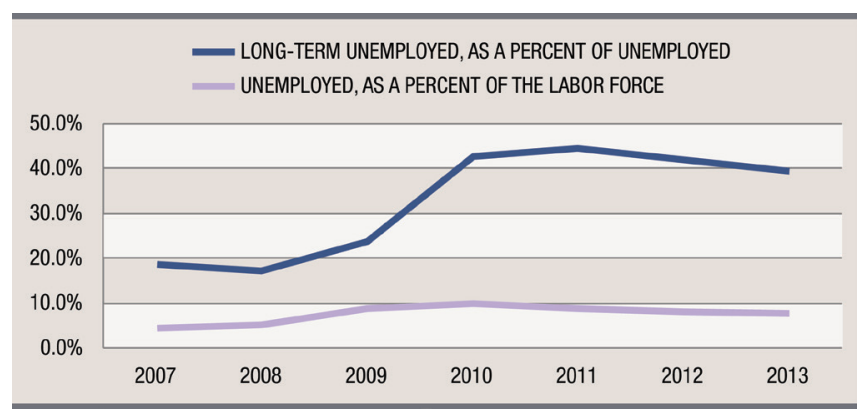

\section{Economic Characteristics of the}

\section{Long-Term Unemployed}

The long-term unemployed are more likely to be in precarious financial situations than compared to the short-term unemployed (see Table 1). ${ }^{6}$ The shortterm unemployed, for instance, have a higher median family income ( $\$ 39,027$ versus $\$ 27,204)$. This pattern holds whether they live in rural or urban locales. However, and partially reflecting the varied cost of

\section{FIGURE 2: LONG-TERM UNEMPLOYED OVER THE YEAR}

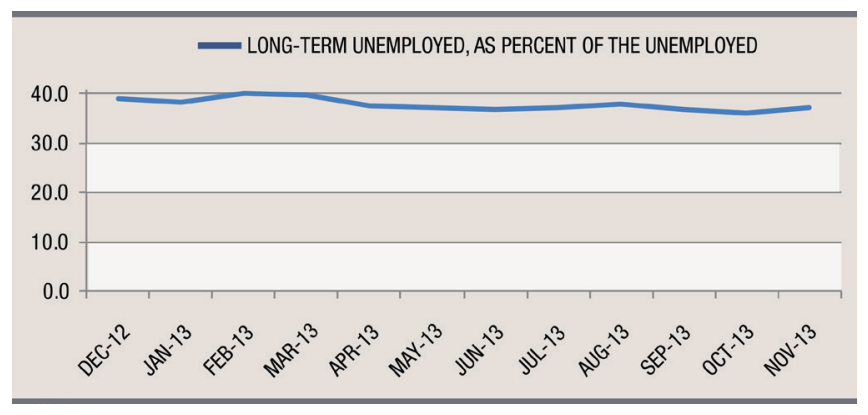

Source: Bureau of Labor Statistics, Employment Situation News Release: Table A-12, December 2012-November 2013.

living between urban and rural places, the long-term unemployed in urban areas have higher median family incomes than their rural counterparts.

The long-term unemployed are also more likely to be in poverty (less than 100 percent of the official poverty line $-\$ 23,283$ for a family of four with two children in 2012) than their short-term counterparts. ${ }^{7}$ Among the long-term unemployed, 35 percent were in poverty in 2012 compared with 26 percent of the short-term unemployed. The same patterns persist across place, with the long-term unemployed in rural areas ( 45 percent) more likely to be in poverty than those in urban places (34 percent).

\section{Demographic Characteristics of the Long-Term Unemployed}

Table 2 displays the demographic characteristics of long- versus short-term unemployed by place. The long-term unemployed, for example, are more likely to live in urban areas ( 87 percent versus 83 percent of the short-term unemployed). As Figure 3 shows, that was not always the case. Since 2010, higher shares of urban residents now count themselves as long-term unemployed, and the gap has continued to widen since then.

The share of women among the long-term unemployed has grown significantly since 2007 (compare Figures 4 and 5). In 2007, for example, approximately 65 percent of the long-term unemployed were men. By 2013, men composed 56 percent of the group. Women in turn composed 35 percent of the long-term unemployed in 2007 and 44 percent in 2013. This research did not find other gender differences in unemployment patterns. 


\section{TABLE 1: ECONOMIC CHARACTERISTICS OF THE SHORT- AND LONG-TERM UNEMPLOYED, BY PLACE TYPE, 2012}

\begin{tabular}{|c|c|c|c|c|c|c|c|c|c|}
\hline & \multicolumn{3}{|c|}{ ALL PLACES } & \multicolumn{3}{|c|}{ RURAL } & \multicolumn{3}{|c|}{ URBAN } \\
\hline & UNEMPLOYED & $\begin{array}{l}\text { SHORT-TERM } \\
\text { UNEMPLOYED }\end{array}$ & $\begin{array}{l}\text { LONG-TERM } \\
\text { UNEMPLOYED }\end{array}$ & UNEMPLOYED & $\begin{array}{l}\text { SHORT-TERM } \\
\text { UNEMPLOYED }\end{array}$ & $\begin{array}{l}\text { LONG-TERM } \\
\text { UNEMPLOYED }\end{array}$ & UNEMPLOYED & $\begin{array}{l}\text { SHORT-TERM } \\
\text { UNEMPLOYED }\end{array}$ & $\begin{array}{l}\text { LONG-TERM } \\
\text { UNEMPLOYED }\end{array}$ \\
\hline MEDIAN FAMILY INCOME & $\$ 34,600.00$ & $\$ 39,027.00$ & $\$ 27,204.00$ & $\$ 30,217.00$ & $\$ 35,999.50$ & $\$ 21,980.00$ & $\$ 35,021.00$ & $\$ 40,000.00$ & $\$ 28,802.00$ \\
\hline \multicolumn{10}{|l|}{ POVERTY STATUS } \\
\hline LESS THAN 100 PERCENT & 29.7 & 26.0 & $35.2^{a}$ & 34.3 & 29.1 & $45.2^{\mathrm{a}}$ & 28.8 & 25.4 & $33.7^{\mathrm{a}, \mathrm{b}}$ \\
\hline 100 TO 199 PERCENT & 22.6 & 21.8 & 23.7 & 22.8 & 21.2 & 26.2 & 22.6 & 22.1 & 23.4 \\
\hline 200 T0 399 & 26.4 & 27.9 & $24.1^{a}$ & 28.6 & 32.2 & $21.3^{\mathrm{a}}$ & 26.0 & 27.0 & $24.4^{\mathrm{a}}$ \\
\hline 400 OR GREATER & 21.4 & 24.2 & $17.1^{\mathrm{a}}$ & 14.2 & 17.6 & $7.4^{\mathrm{a}}$ & 22.7 & 25.5 & $18.5^{\mathrm{a}, \mathrm{b}}$ \\
\hline
\end{tabular}

Source: Annual Social and Economic Supplement, Current Population Survey, 2013

Notes: a indicates a statistically significant $(p<.05)$ difference between short- and long-term unemployed; $b$ indicates a statistically significant $(p<.05)$ difference between rural and urban place type for long-term unemployed.

TABLE 2: DEMOGRAPHIC CHARACTERISTICS OF THE SHORT- AND LONG-TERM UNEMPLOYED, BY PLACE TYPE, 2013

\begin{tabular}{|c|c|c|c|c|c|c|c|c|c|}
\hline & \multicolumn{3}{|c|}{ ALL PLACES } & \multicolumn{3}{|c|}{ RURAL } & \multicolumn{3}{|c|}{ URBAN } \\
\hline & UNEMPLOYED & $\begin{array}{l}\text { SHORT-TERM } \\
\text { UNEMPLOYED }\end{array}$ & $\begin{array}{l}\text { LONG-TERM } \\
\text { UNEMPLOYED }\end{array}$ & UNEMPLOYED & $\begin{array}{l}\text { SHORT-TERM } \\
\text { UNEMPLOYED }\end{array}$ & $\begin{array}{l}\text { LONG-TERM } \\
\text { UNEMPLOYED }\end{array}$ & UNEMPLOYED & $\begin{array}{l}\text { SHORT-TERM } \\
\text { UNEMPLOYED }\end{array}$ & $\begin{array}{l}\text { LONG-TERM } \\
\text { UNEMPLOYED }\end{array}$ \\
\hline PERCENT OF UNEMPLOYED & 100.0 & 60.7 & 39.3 & 15.1 & 67.3 & 32.8 & 84.9 & 59.5 & 40.5 \\
\hline \multicolumn{10}{|l|}{ PLACE TYPE } \\
\hline RURAL & 15.1 & 16.8 & $12.6^{\mathrm{a}}$ & NA & NA & NA & NA & NA & NA \\
\hline URBAN & 84.9 & 83.2 & $87.4^{\mathrm{a}}$ & NA & NA & NA & NA & NA & NA \\
\hline \multicolumn{10}{|l|}{ GENDER } \\
\hline MALE & 56.2 & 56.2 & 56.2 & 55.5 & 57.2 & 52.2 & 56.2 & 56.0 & 56.7 \\
\hline FEMALE & 43.8 & 43.8 & 43.8 & 44.5 & 42.8 & 48.0 & 43.8 & 44.0 & 43.3 \\
\hline \multicolumn{10}{|l|}{ AGE } \\
\hline 16 TO 19 & 10.6 & 13.6 & $6^{\mathrm{a}}$ & 12.2 & 13.6 & $9.4^{\mathrm{a}}$ & 10.3 & 13.6 & $5.5^{a, b}$ \\
\hline 20 T0 24 & 16.8 & 19.1 & $13.3^{\mathrm{a}}$ & 18.2 & 19.1 & 16.3 & 16.5 & 19.1 & $12.8^{\mathrm{a}}$ \\
\hline 25 T0 34 & 22.2 & 22.9 & 20.9 & 21.7 & 21.1 & 22.6 & 22.3 & 23.2 & $20.7^{\mathrm{a}}$ \\
\hline 35 TO 44 & 17.3 & 16.3 & $18.7^{\mathrm{a}}$ & 16.3 & 16.5 & 16.1 & 17.4 & 16.3 & $19^{a}$ \\
\hline 45 TO 54 & 17.3 & 15.2 & $20.5^{a}$ & 17.2 & 16.2 & 19.0 & 17.3 & 15.0 & $20.8^{\mathrm{a}}$ \\
\hline 55 T0 64 & 11.9 & 9.6 & $15.4^{\mathrm{a}}$ & 10.5 & 10.0 & 11.7 & 12.1 & 9.5 & $15.9^{a, b}$ \\
\hline 65 AND OVER & 4.0 & 3.3 & $5.2^{\mathrm{a}}$ & 3.1 & 3.3 & 4.9 & 4.1 & 3.2 & $5.3^{\mathrm{a}}$ \\
\hline \multicolumn{10}{|l|}{ RACE/ETHNICITY } \\
\hline WHITE, NON-HISPANIC & 54.2 & 55.5 & $52.2^{a}$ & 72.0 & 74.5 & $66.6^{\mathrm{a}}$ & 51.1 & 51.7 & $50.2^{b}$ \\
\hline BLACK, NON-HISPANIC & 19.6 & 17.1 & $23.4^{\mathrm{a}}$ & 12.4 & 10.1 & $17.2^{\mathrm{a}}$ & 20.8 & 18.5 & $24.4^{\mathrm{a}, \mathrm{b}}$ \\
\hline OTHER, NON-HISPANIC & 7.1 & 6.7 & 7.5 & 6.8 & 6.0 & 8.5 & 7.1 & 6.9 & 7.4 \\
\hline HISPANIC & 19.2 & 20.6 & $16.8^{\mathrm{a}}$ & 8.8 & 9.3 & 7.7 & 21.0 & 23.0 & $18^{a, b}$ \\
\hline \multicolumn{10}{|l|}{ EDUCATION } \\
\hline LESS THAN HIGH SCHOOL & 20.9 & 22.4 & $18.6^{a}$ & 23.0 & 22.5 & 24.2 & 20.5 & 22.3 & $17.7^{a, b}$ \\
\hline HIGH SCHOOL GRADUATE & 34.7 & 34.1 & 35.6 & 42.2 & 42.8 & 40.7 & 33.4 & 32.4 & 34.8 \\
\hline SOME COLLEGE & 27.6 & 28.3 & 26.6 & 26.9 & 27.0 & 26.7 & 27.6 & 28.4 & 26.6 \\
\hline COLLEGE GRADUATE OR MORE & 16.8 & 15.2 & $19.3^{\mathrm{a}}$ & 7.9 & 7.6 & 8.4 & 18.5 & 16.8 & $20.9^{\mathrm{a}, \mathrm{b}}$ \\
\hline \multicolumn{10}{|l|}{ FAMILY STRUCTURE } \\
\hline MARRIED WITH KIDS & 20.1 & 20.4 & 19.7 & 17.3 & 19.5 & 12.7 & 20.6 & 20.5 & $20.7^{b}$ \\
\hline MARRIED WITHOUT KIDS & 13.3 & 12.3 & $14.8^{\mathrm{a}}$ & 14.6 & 14.3 & 15.1 & 13.0 & 11.9 & $14.7^{\mathrm{a}}$ \\
\hline SINGLE WITH KIDS & 13.9 & 13.7 & 14.2 & 17.1 & 15.7 & 20.0 & 13.3 & 13.2 & $13.4^{b}$ \\
\hline SINGLE WITHOUT KIDS & 52.7 & 53.7 & 51.4 & 51.1 & 50.5 & 52.3 & 53.0 & 54.3 & $51.2^{\mathrm{a}}$ \\
\hline
\end{tabular}

Source: Annual Social and Economic Supplement, Current Population Survey, 2013.

Notes: a indicates a statistically significant $(p<.05)$ difference between short- and long-term unemployed; $b$ indicates a statistically significant $(p<.05)$ difference between place type for long-term unemployed. 
FIGURE 3: PERCENT OF THE LONG-TERM UNEMPLOYED OF TOTAL UNEMPLOYED IN URBAN AND RURAL AREAS

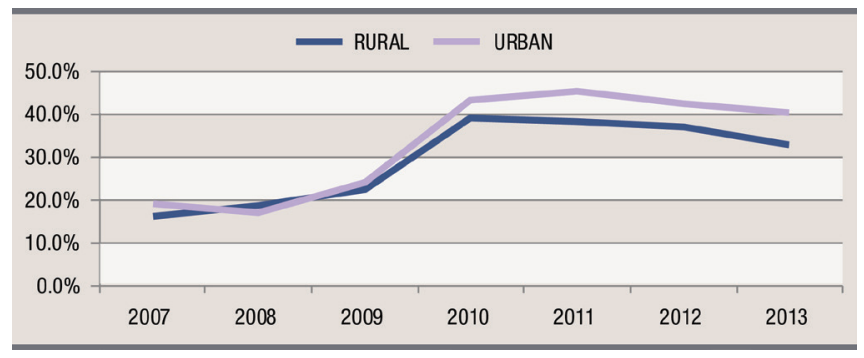

Note: Rural/urban differences statistically significant $(p<.05)$ starting 2010.

\section{FIGURE 4: DIMINISHING GENDER GAP AMONG THE LONG-TERM UNEMPLOYED, 2007 AND 2013}

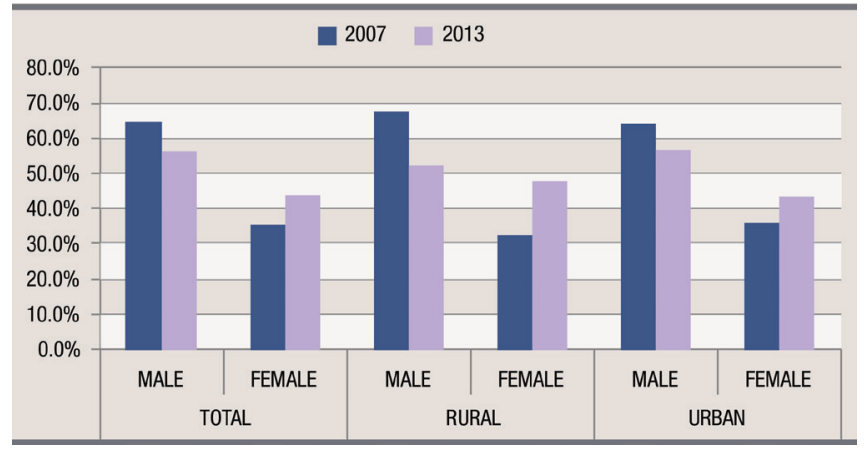

Note: All year-to-year gender differences statistically significant $(p<.05)$.

Table 2 also shows racial differences between the short- and long-term unemployed. In 2013, approximately one-half of the long-term unemployed were non-Hispanic white. Approximately one-fourth were non-Hispanic black, approximately 17 percent were Hispanic, and 8 percent were non-Hispanics of other races. There are also differences between the long- and short-term unemployed. The long-term unemployed are less likely to be non-Hispanic white (52 versus 56 percent of short-term unemployed) or Hispanic (17 percent versus 21 percent), and they are more likely to be non-Hispanic black (23 versus 17 percent).

These general patterns persist across place but are exaggerated in rural areas. There, two-thirds of the long-term unemployed are non-Hispanic white versus three-fourths of the short-term unemployed in rural places. Likewise, 17 percent of the long-term unemployed in rural areas are non-Hispanic black. This number is only 10 percent among the short-term unemployed. The magnitude of these differences in rural areas is likely due, in large part, to less overall diversity in rural America. Nonetheless, the general pattern persists across place.

There are also substantial educational differences among the short- and long-term unemployed. The long-term unemployed are more likely to have a college or advanced degree than the short-term unemployeda relatively new phenomenon (see Figure 5). Mirroring educational disparities in urban and rural areas, in general, these education differences are driven by those living in urban areas. Only 8 percent of the rural longterm unemployed had a college degree in 2013, compared with 21 percent of their urban counterparts. The long-term unemployed are also older, however, than their short-term unemployed counterparts. It is possible that the relative "youth" of the short-term unemployed group leaves them less likely to have attained a college or advanced degree.

\section{FIGURE 5: PERCENT WITH COLLEGE OR ADVANCED DEGREE BY PLACE, 2007 AND 2013}

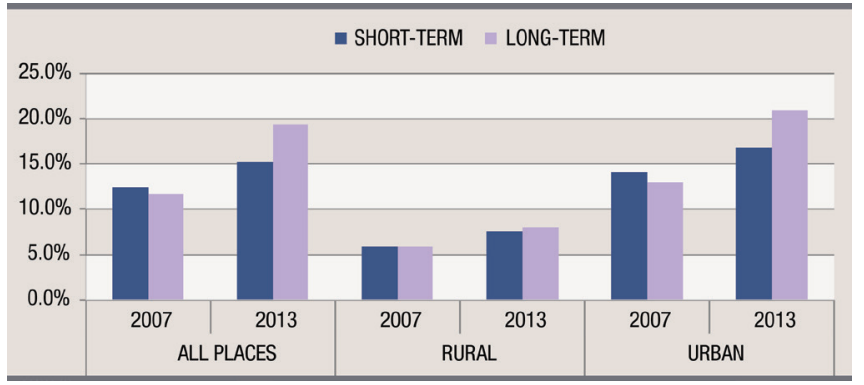

Note: All year-to-year gender differences statistically significant $(\mathrm{p}<.05)$.

Family structure also differs. ${ }^{8}$ Analyses suggest the long-term unemployed are more likely than the shortterm unemployed to be married without children under age 18. Also, one-in-five of the long-term unemployed in urban areas are married with children, twice the proportion of their rural counterparts (a little more than one-in-ten). Furthermore, the urban long-term unemployed are less likely to be single parents than their rural counterparts. As with the education findings, it is possible that differences in family structure stem from substantial age differences between the two groups. The rural long-term unemployed might be less likely to be married with children because they are younger and, therefore, less likely to have reached a stage in the life course where having children is a reasonable goal. 


\section{Policy Implications}

The basic unemployment insurance program in the United States is administered by the states with most states providing up to twenty-six weeks of unemployment insurance benefits for qualified workers. While eligibility for these benefits varies somewhat by state, workers are considered to be qualified if they lost their job through no fault of their own and are actively looking for work, are available and able to work, are not a new- or re-entrant to the labor force, and have earned enough during a "base period" of employment before becoming unemployed. ${ }^{9}$ In response to the Great Recession, the federal government enacted the Emergency Unemployment Compensation (EUC) program to finance additional weeks of unemployment benefits in states where unemployment had reached a certain threshold. ${ }^{10}$ The EUC program was initially meant to serve as a temporary response to the recession but was extended as a result of persistently high long-term unemployment rates.

These EUC benefits expired on January 1, 2014, although Congress took up debate on their extension shortly thereafter. Policy makers and advocates are calling for an extension to the program ${ }^{11}$ amidst ongoing debate in the Congress regarding the reinstatement of EUC. It is beyond the scope of this brief to perform analyses of unemployment compensation benefits. The data presented here do not isolate workers who would be directly affected by letting the EUC program expire. However, all those who would be affected by any change to EUC fall within the long-term unemployed group studied here, and as of January their benefits ceased.

As debate about the extension of EUC benefits continues, it is important to gain an understanding of the long-term unemployed in terms of their demographic and economic characteristics and how those characteristics differ across place. Doing so can help better target strategies for alleviating the negative effects of longterm unemployment. Job training policies, for example, will look different if the long-term unemployed are older or younger, urban or rural. As our results show, for example, the long-term unemployed are disproportionately older. Understanding their situations can help design programs that support both them and their children. Similarly, Hispanics appear to be less affected by long-term unemployment. How they reattach to the workforce could inform other job-training programs.
Understanding who is struggling can also inform other safety net programs. Young workers may need less support in their twenties than older workers in their fifties when they are out of work, whose prospects of returning to a well-paying late-career job are dim at a time when retirement savings should be at its peak. Knowledge of the demographic and economic distribution of the long-term unemployed can help inform these and other decisions.

\section{Data}

The data used are from the 2007-2013 Annual Social and Economic Supplement (ASEC) of the Current Population Survey (CPS). Initially conducted by the Bureau of Labor Statistics and the U.S. Census Bureau to measure unemployment, the CPS is conducted monthly on a sample of about 50,000 households. The ASEC, conducted in March, asks a number of questions about income, employment, and other aspects of labor force behavior. It is important to note that newer CPS data exist. We did not use those newer data here because we would lose the breadth of economic variables included in the ASEC. That said, March was a time of relatively high long-term unemployment compared with other surrounding months. For instance, in the most recent CPS release (November), the long-term unemployed make up a slightly smaller proportion of the total unemployed population (37.3 percent) than reported here using the ASEC (39.3 percent). Furthermore, the average percent of the unemployed seeking work long-term over the past year is 37.8 percent (see Figure 2).

Because the CPS is based on a sample of the population, readers should be cautious when comparing differences between groups. Although some categories might appear different from others, it is possible that the disparity is due to sampling error. Likewise, small differences may be statistically significant owing to the large sample size of the CPS. Nonetheless, all differences discussed in this brief are statistically significant at the $\mathrm{p}<.05$ level. Data are weighted to adjust for the complex sampling design of the CPS and on the basis of age, race/ethnicity, and sex. 


\section{Box 1: Short- and Long-Term Unemployed}

The CPS asks questions about labor force participation in the week prior to the interview and splits the civilian labor force (aged 16 and older) into three categories: those not in the labor force, those who are employed, and those who are unemployed. The unemployed includes those individuals who were actively looking for work and able to work in the previous week, but were otherwise not employed. ${ }^{12}$ For this brief, the unemployed are separated into two groups based on duration of unemployment:

- Short-term unemployed ${ }^{13}$ : Those who have been unemployed for twenty-six or fewer weeks.

- Long-term unemployed: Those who have been unemployed for more than twenty-six weeks, roughly six months.

\section{Box 2: Rural and Urban Places}

Definitions of rural and urban vary among researchers and the sources of data they use. Data for this brief are from the Current Population Survey, which indicates whether each household is or is not located in a metropolitan area. The Office of Management and Budget defines metropolitan areas as: (1) a central county (or counties) containing at least one urbanized area with a population of at least 50,000 people, and (2) the counties that are socially and economically integrated with the urbanized area, as measured by commuting patterns. In this brief, urban refers to such metropolitan places, and rural refers to nonmetropolitan places outside these boundaries.

\section{End notes}

1. See the most recent Economic News Release regarding the Employment Situation Summary from the Bureau of Labor Statistics at www.bls.gov/news.release/empsit.nr0.htm (retrieved November 23, 2013).

2. For notable exceptions, see: Donna S. Rothstein, "Longterm Unemployment Over Men's Careers," Beyond the Numbers: Employment and Unemployment, vol. 2, no. 21 (U.S. Bureau of Labor Statistics, August 2013), www.bls.gov/opub/ btn/volume-2/long-term-unemployment-over-mens-careers. htm (retrieved November, 22, 2013); Sylvia Allegretto and Devon Lunch, "The Composition of the Unemployed and Long-Term Unemployed in Tough Labor Markets," Monthly Labor Review, October 2010.

3. See Box 1 for more detailed definition of the long-term unemployed.

4. Unemployment insurance is available for a maximum of twenty-six weeks. Jobless benefits, however, have been extended beyond the twenty-six weeks during long-lasting recessions, including the current one. Congress at the time of this writing was debating whether to continue the extension. In addition, eight states offer fewer than twenty-six weeks: Michigan, Georgia, Florida, Missouri, South Carolina, Arkansas, Illinois and Florida; Montana and Massachusetts offer more than twenty-six weeks.

5. See, Josh Mitchell, "Who Are the Long-Term Unemployed?" Urban Institute, July 2013 for a notable exception.

6. The data in this table refer to 2012 because questions about income and poverty are asked about the previous year. As a result, it is possible that the long-term unemployed worked for pay for part of the period.

7. The poverty threshold for a family of four was $\$ 23,283$ in 2012. A person's poverty status is determined by comparing their "total family income" to a "threshold" based on family size and presence of children. Those with a total family income below the threshold for a family of that size and structure are considered to be in poverty. If a family is categorized as "in poverty," then all members of that family are considered to be in poverty. For more on the Census Bureau's definitions of poverty and calculations of thresholds, visit its website: www.census.gov/hhes/www/poverty/ data/threshld (retrieved December 2, 2013). 
8. We group them here as married with children under 18 , married without children under 18 , single with children under 18, and single without children under 18 .

9. See Chad Stone and William Chen, "Introduction to Unemployment Insurance" (Center on Budget and Policy Priorities, February 6, 2013), www.cbpp.org/cms/index. $\mathrm{cfm}$ ?fa=view\&id=1466 (retrieved November 22, 2013).

\section{Ibid.}

11. For instance, Lawrence Mishel and Heidi Shierholz, "Labor Market Will Lose 310,000 Jobs in 2014 If Unemployment Insurance Extensions Expire," Economic and Policy Institute, November 7, 2013, www.epi.org/publication/labormarket-lose-310000-jobs-2014-unemployment (retrieved November 22, 2013); Issue Brief, "More Than Two Million Unemployed Workers Will Lose Jobless Aid By Early 2014

If Congress Allows Federal Benefits to Shut Down at Year's End," National Law Employment Project, November 2013, www.nelp.org/page/-/UI/2013/Issue-Brief-Two-MillionUnemployed-Lose-Federal-Jobless-Aid-Shut-Down. pdf?nocdn=1 (retrieved November 22, 2013).

12. For more on who counts as unemployed, see this Bureau of Labor Statistics report titled "How the Government Measures Employment” (Washington, DC: BLS, n. d.). Available at www. bls.gov/cps/cps_htgm.htm (retrieved November 22, 2013).

13. The name "short-term" is used as a convention in this brief to ease the discussion and comparison between the two groups. The unemployment duration of this group is not necessarily "short," however, considering it can range from one week to six months.

\section{About the Author}

Andrew Schaefer is a doctoral candidate in sociology at the University of New Hampshire and a research assistant at the Carsey Institute (andrew.schaefer@unh.edu).

\section{A ck n ow led g me n t s}

The author thanks Austin Nichols at the Urban Institute and Mike Evangelist at the National Employment Law Project; Jessica Carson, Marybeth Mattingly, Michele Dillon, Bruce Mallory, Curt Grimm, Amy Sterndale, and Laurel Lloyd at the Carsey Institute; and Barbara Ray at Hired Pen for their helpful comments and suggestions. 


\section{A UNIVERSITY A of NEW HAMPSHIRE}

\section{CARSEY \\ I N S T I T U T E}

Building knowledge for families and communities

The Carsey Institute conducts policy research on vulnerable children, youth, and families and on sustainable community development. We give policy makers and practitioners timely, independent resources to effect change in their communities.

This work was supported by the Annie E. Casey Foundation, the W. K. Kellogg Foundation, and anonymous donors.

Huddleston Hall

73 Main Street

Durham, NH 03824

(603) 862-2821

TTY UsERS: DIAL 7-1-1 OR 1-800-735-2964 (RELAY N.H.)

www.carseyinstitute.unh.edu 